\begin{tabular}{|c|l|}
\hline Title & $\begin{array}{l}\text { A symmetric and efficient synthesis of homopheny lal anine derivatives via Friedel-Crafts reaction with } \\
\text { trifluoromethanesulfonic acid }\end{array}$ \\
\hline Author(s) & Murashige, Ryo; Hay ashi, Y uka; Hashimoto, Makoto \\
\hline Citation & $\begin{array}{l}\text { Tetrahedron Letters, 49(46), 6566-6568 } \\
\text { https:/doi.org/10.1016/.tetlet.2008.09.013 }\end{array}$ \\
\hline Issue Date & 2008 11-10 \\
\hline Doc URL & http://hdl.handle.net/2115/64916 \\
\hline Rights & ○ 2017 Elsevier Science \\
\hline Type & article (author version) \\
\hline File Information & 20 TL 496566-6568.pdf \\
\hline
\end{tabular}

Instructions for use 


\title{
Asymmetric and efficient synthesis of homophenylalanine derivatives via Friedel-Crafts reaction with trifluoromethanesulfonic acid
}

\author{
Ryo Murashige, Yuka Hayashi and Makoto Hashimoto * \\ Department of Agricultural and Life Science, Obihiro University of Agriculture and Veterinary Medicine, Inada-cho,
}

Obihiro 080-8555, Hokkaido, Japan

\begin{abstract}
An efficient Friedel-Crafts reaction of TFA-Asp(Cl)-OMe and stoichiometric amounts of benzene was established by using neat trifluoromethanesulfonic acid (TfOH) as solvent and catalyst under a mild condition. This methodology has been applied to many aromatic compounds and enabled synthesis of several homophenylalanine derivatives. (c) 2017 Elsevier Science. All rights reserved
\end{abstract}

\section{Introduction}

Homophenylalanine (hPhe) elongates methylene in a side chain of phenylalanine (Phe). Sometimes it produces different biological activities when displacing Phe with homoPhe in bioactive peptides. ${ }^{1}$ hPhe is also known as a starting material for pharmaceutical products such as benazepril and enarapril, which inhibit angiotensin converting enzyme (ACE). ${ }^{2}$ Asymmetric and efficient synthesis of hPhe is important. Synthesis of hPhe has been reported using various methodologies including enzymatic resolution, ${ }^{3}$ Suzuki-coupling, ${ }^{4}$ diastereoselective Michel addition $^{5}$ and catalytic asymmetric hydrogenation. ${ }^{6}$ These methods require the preparation of special reagents or precursors for the asymmetric synthesis of both enantiomers. Amino acids are one of the most popular precursors and easily available for asymmetric synthesis. Friedel-Crafts (FC) reactions between aromatics and a side chain of aspartic acid (Asp) are some of the key reactions for asymmetric synthesis for both hPhe enantiomers' skeletons. ${ }^{7}$ It has been reported that synthesis of hPhe using F-C reaction of Asp anhydride ( $N$-unprotected or $N$-protected) by $\mathrm{AlCl}_{3}$ is required for large excesses of aromatics and refluxing in organic solvent for long durations. Smaller amounts of aromatics at room temperature have produced lower yields. $^{7 \mathrm{~b}}$ It is estimated that the low solubility of Asp derivatives makes the reaction mixture precipitate in organic solvents. Therefore the synthetic routes have not been applied to precious or pyrolyzing aromatic compounds. To apply these synthetic routes to many aromatic compounds, we established an efficient Friedel-Crafts reaction with stoichiometric amounts of enantiopure Asp derivatives and aromatics at low temperature, followed by derivatization to hPhe.

\section{Results and Discussion}

To establish an efficient F-C reaction, conditions, which consisted of aromatics and acyl donors stoichiometrically at room temperature, were fixed. One of the most popular acyl donors, $N$-TFA-protected L-Asp anhydride $(\mathbf{1})^{8}$, was used as a first choice because an acid stable $N$-protection group might be preferable for the $\mathrm{F}-\mathrm{C}$ reaction. Using $\mathrm{AlCl}_{3}$ (Table 1, Entry 1) as a catalyst in $\mathrm{CH}_{2} \mathrm{Cl}_{2}$, no reaction occurred within 12 hours because the ${ }_{\mathrm{L}}$-Asp derivative was precipitated. ${ }^{9}$ To resolve the problem, we attempted F-C reactions in excess amounts of liquid promoters, which we used as a solvent. $\mathrm{TiCl}_{4}$, which is normally used for an F-C reaction for the $\alpha$-carboxyl in $\alpha$-amino acid, ${ }^{10}$ was used (Entry 2). However the reaction mixture became heterogeneous and no reaction was observed. We chose concentrated $\mathrm{H}_{2} \mathrm{SO}_{4}$ (Entry 3) to make the reaction mixture homogeneous, but only a hydrolyzed product of acyl donor ( $N$-TFA- $\left.-_{\mathrm{L}}-\mathrm{Asp}-\mathrm{OH}\right)$ was obtained. This result showed that compound 1 could be dissolved in strong Bronsted acid. We tried using a neat trifluoromethanesulfonic acid (TfOH) as a promoter and solvent. TfOH has been used in F-C reactions because it forms mixed anhydride which has a strong reactivity with acyldonor. ${ }^{11}$ As shown in Entry 4, the reaction mixture became homogeneous in $\mathrm{TfOH}$, the $\mathrm{F}-\mathrm{C}$ reaction proceeded within an hour at room temperature to obtain target compounds (4a and $\mathbf{4 b}$ ) in $55 \%$ yield and no

\footnotetext{
* Corresponding author. Tel.: +81-155495542; fax: +81-155495577; e-mail: hasimoto@obihiro.ac.jp.
} 
hydrolysis of 1 was observed. To ensure the role of $\mathrm{TfOH}$, $\mathrm{Tf}_{2} \mathrm{O}$ (Entry 5), which was reported as an F-C when forming mixed anhydride with carboxylic acid ${ }^{12}$, was applied. The reaction mixture became heterogeneous and no reaction occurred. These results showed that TfOH not only improved the solubility of $\mathbf{1}$ but also promoted an effective F-C reaction effectively. A regioisomer was formed in the condition, because compound $\mathbf{1}$ had two F-C reaction sites, $\beta$ - and $\alpha$ - carboxyl, $(\mathbf{4 a}: \mathbf{4 b}=95: 5)$. The proportion of the regioisomer was identical to that used in previous reports, which used $\mathrm{AlCl}_{3}$ in excess benzene with refluxing. ${ }^{8} \mathrm{~N}$ unprotected L-Asp anhydride (2) ${ }^{13}$, which is another popular donor, was subjected to the F-C condition in $\mathrm{TfOH}$, and no products were formed because the reaction mixture became heterogeneous (Entry 6). To improve the reaction, TFA- ${ }_{\mathrm{L}^{-}}$ Asp(Cl)-OMe (3) that was obtained via methanolyzing 1 with $\mathrm{MeOH}$, then treating the product with $\mathrm{SOCl}_{2}$, ${ }^{14}$ was used as an acyl donor. As expected, that compound $\mathbf{3}$ was more reactive than $\mathbf{1}$ or $\mathbf{2}$ and it had only one acylation site heterogeneous. $\mathrm{TiCl}_{4}$ and $\mathrm{H}_{2} \mathrm{SO}_{4}$ did not afford the $\mathrm{F}-\mathrm{C}$ product 5 because it was a heterogeneous mixture and hydrolysis of acyl donor occurred respectively (Entries 8 and 9). A homogeneous mixture was made using $\mathrm{TfOH}$ and compound $\mathbf{3}$ was converted to 5 in a $98 \%$ yield within an hour (Entry 10). The F-C reaction using $\mathrm{Tf}_{2} \mathrm{O}$ is not effective because $\mathrm{Tf}_{2} \mathrm{O}$ did not dissolve the acyl donor during the reaction (Entry 11). There were some benefits to using acyl donor $\mathbf{3}$ in TfOH. First, F-C reaction proceeded on a small scale $(<0.1 \mathrm{mmol})$ in a mild condition $\left(0{ }^{\circ} \mathrm{C}\right)$ and produced a high yield. Second, further purification was not needed by ${ }^{1} \mathrm{H}-\mathrm{NMR}$ analysis after the reaction mixture was subjected to partition $\left(1 \mathrm{~N} \mathrm{HCl}\right.$, saturated $\mathrm{NaHCO}_{3}$. and saturated $\mathrm{NaCl}){ }^{15}$ From these results, this F-C reaction with neat $\mathrm{TfOH}$ could be applied to various aromatic compounds.<smiles>O=C1C[C@H](NC(F)F)C(=O)O1</smiles>

1<smiles>N[C@@H]1CC(=O)OC1=O</smiles>

2

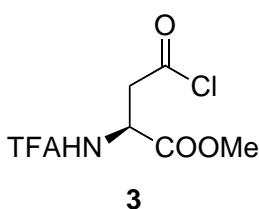

Figure 1. Acyl donors for Friedel-Crafts reaction with benzene
1 or 2 or $3+$ $1 e q$<smiles>c1ccccc1</smiles>

\section{Catalyst Condition}

to prevent formation of a regiteisomer. Although stoichiometric amounts of benzene and $\mathbf{3}$ in the presence of $\mathrm{AlCl}_{3}$ in $\mathrm{CH}_{2} \mathrm{Cl}_{2}$ afforded a moderate yield of $\mathrm{F}-\mathrm{C}$ products 5 in moderate yield (Entry 7), a long reaction time was needed (10 hours) because the reaction mixture became<smiles>[R]OC(=O)[C@@H](CC(=O)c1ccccc1)N=[In]</smiles><smiles>O=C(O)C[C@H](NC(F)F)C(=O)c1ccccc1</smiles>

$4 a \mathrm{R}=\mathrm{H}$

$5 \mathrm{R}=\mathrm{Me}$
TFAHN

4b

\begin{tabular}{cccccc}
\hline Entry & Donor & Catalyst (eq) & Solvent & Reaction time (h) & Product yield (\%) \\
\hline 1 & $\mathbf{1}$ & $\mathrm{AlCl}_{3}(8)$ & $\mathrm{CH}_{2} \mathrm{Cl}_{2}$ & 1 or 12 & 0 \\
2 & $\mathbf{1}$ & $\mathrm{TiCl}_{4}(90)$ & neat & 1 or 12 & 0 \\
3 & $\mathbf{1}$ & $\mathrm{H}_{2} \mathrm{SO}_{4}(90)$ & neat & 1 or 12 & 0 \\
4 & $\mathbf{1}$ & $\mathrm{TfOH}^{(40)}$ & neat & 1 & $\mathbf{4 a}(52), \mathbf{4 b}(3)$ \\
5 & $\mathbf{1}$ & $\mathrm{Tf}_{2} \mathrm{O}(25)$ & neat & 1 or 12 & 0 \\
6 & $\mathbf{2}$ & $\mathrm{TfOH}^{(40)}$ & neat & 1 & 0 \\
7 & $\mathbf{3}$ & $\mathrm{AlCl}_{3}(8)$ & $\mathrm{CH}_{2} \mathrm{Cl}$ & 10 & $\mathbf{5}(50)$ \\
8 & $\mathbf{3}$ & $\mathrm{TiCl}_{4}(90)$ & neat & 1 or 12 & 0 \\
9 & $\mathbf{3}$ & $\mathrm{H}_{2} \mathrm{SO}_{4}(90)$ & neat & 1 or 12 & 0 \\
10 & $\mathbf{3}$ & $\mathrm{TfOH}^{(40)}$ & neat & 1 & $\mathbf{5}(98)$ \\
11 & $\mathbf{3}$ & $\mathrm{Tf}_{2} \mathrm{O}(25)$ & neat & 1 or 12 & 0 \\
\hline
\end{tabular}

Table 1. Friedel-Crafts reaction of $\mathbf{1}$ or $\mathbf{2}$ or $\mathbf{3}$ and stoichiometric amounts of benzene at room temperature by catalysts 
<smiles>[R4]c1cc([R1])c([R2])c([R3])c1</smiles>

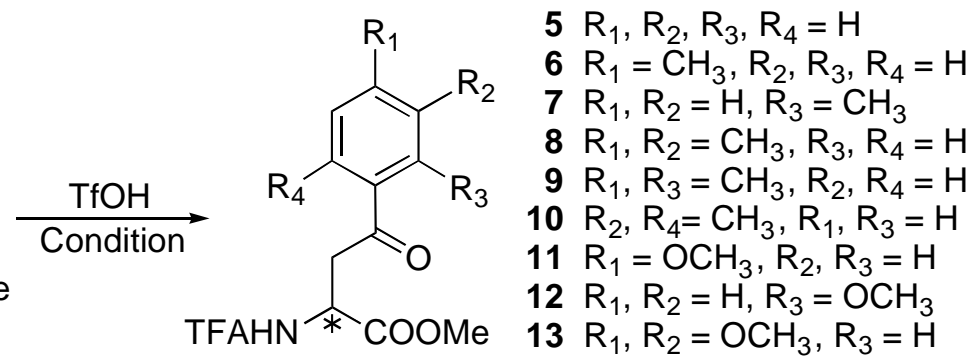

\begin{tabular}{|c|c|c|c|c|c|c|c|c|}
\hline Entry & $\mathrm{R}_{1}$ & $\mathrm{R}_{2}$ & $\mathrm{R}_{3}$ & $\mathrm{R}_{4}$ & Configuration of $\mathbf{3}$ & Conditions & $\begin{array}{c}\text { Product } \\
\text { (proportion }^{\mathrm{a}} \text { ) }\end{array}$ & Yield (\%) \\
\hline 1 & $\mathrm{H}$ & $\mathrm{H}$ & $\mathrm{H}$ & $\mathrm{H}$ & L- & $0^{\circ} \mathrm{C}$-r.t., $1 \mathrm{~h}$ & $\mathrm{~L}-5$ & 98 \\
\hline 2 & $\mathrm{H}$ & $\mathrm{H}$ & $\mathrm{H}$ & $\mathrm{H}$ & D- & $0^{\circ} \mathrm{C}$-r.t., $1 \mathrm{~h}$ & $\mathrm{D}-5$ & 97 \\
\hline 3 & $\mathrm{Me}$ & $\mathrm{H}$ & $\mathrm{H}$ & $\mathrm{H}$ & L- & $0^{\circ} \mathrm{C}, 1 \mathrm{~h}$ & $\mathrm{~L}^{-\mathbf{6}, 7} \mathbf{7}(95: 5)$ & 99 \\
\hline 4 & $\mathrm{Me}$ & $\mathrm{H}$ & $\mathrm{H}$ & $\mathrm{H}$ & D- & $0^{\circ} \mathrm{C}, 1 \mathrm{~h}$ & ${ }^{\mathrm{D}} \mathbf{6} \mathbf{6}, 7$ (95: 5) & 99 \\
\hline 5 & $\mathrm{Me}$ & $\mathrm{Me}$ & $\mathrm{H}$ & $\mathrm{H}$ & L- & $0^{\circ} \mathrm{C}, 1 \mathrm{~h}$ & $L^{-}-\mathbf{8}$ & 97 \\
\hline 6 & $\mathrm{Me}$ & $\mathrm{Me}$ & $\mathrm{H}$ & $\mathrm{H}$ & D- & $0^{\circ} \mathrm{C}, 1 \mathrm{~h}$ & $\mathrm{D}-\mathbf{8}$ & 96 \\
\hline 7 & $\mathrm{Me}$ & $\mathrm{H}$ & $\mathrm{Me}$ & $\mathrm{H}$ & L- & $0^{\circ} \mathrm{C}, 1 \mathrm{~h}$ & L-9 & 98 \\
\hline 8 & $\mathrm{Me}$ & $\mathrm{H}$ & $\mathrm{Me}$ & $\mathrm{H}$ & D- & $0^{\circ} \mathrm{C}, 1 \mathrm{~h}$ & D-9 & 98 \\
\hline 9 & $\mathrm{H}$ & $\mathrm{Me}$ & $\mathrm{H}$ & Me & L- & $0^{\circ} \mathrm{C}, 1 \mathrm{~h}$ & $\mathrm{~L}-\mathbf{1 0}$ & 96 \\
\hline 10 & $\mathrm{H}$ & $\mathrm{Me}$ & $\mathrm{H}$ & $\mathrm{Me}$ & D- & $0^{\circ} \mathrm{C}, 1 \mathrm{~h}$ & $\mathrm{D}-\mathbf{1 0}$ & 97 \\
\hline 11 & $\mathrm{OMe}$ & $\mathrm{H}$ & $\mathrm{H}$ & $\mathrm{H}$ & L- & $0^{\circ} \mathrm{C}, 1 \mathrm{~h}$ & ${ }_{L}-\mathbf{1 1}, \mathbf{1 2}(5: 4)$ & 97 \\
\hline 12 & OMe & $\mathrm{H}$ & $\mathrm{H}$ & $\mathrm{H}$ & D- & $0^{\circ} \mathrm{C}, 1 \mathrm{~h}$ & $\mathrm{D}-\mathbf{1 1}, \mathbf{1 2}(5: 4)$ & 98 \\
\hline 13 & OMe & OMe & $\mathrm{H}$ & $\mathrm{H}$ & L- & $0^{\circ} \mathrm{C}, 1 \mathrm{~h}$ & ${ }_{L}-13$ & 99 \\
\hline 14 & OMe & OMe & $\mathrm{H}$ & $\mathrm{H}$ & D- & $0^{\circ} \mathrm{C}, 1 \mathrm{~h}$ & $\mathrm{D}-\mathbf{1 3}$ & 99 \\
\hline 15 & $\mathrm{NO}_{2}$ & $\mathrm{H}$ & $\mathrm{H}$ & $\mathrm{H}$ & L- & $0^{\circ} \mathrm{C}$-r.t., $1 \mathrm{~h}$ & - & 0 \\
\hline 16 & NHAc & $\mathrm{H}$ & $\mathrm{H}$ & $\mathrm{H}$ & L- & $0^{\circ} \mathrm{C}$-r.t., $1 \mathrm{~h}$ & - & 0 \\
\hline 17 & NHTFA & $\mathrm{H}$ & $\mathrm{H}$ & $\mathrm{H}$ & L- & $0^{\circ} \mathrm{C}$-r.t., $1 \mathrm{~h}$ & - & 0 \\
\hline
\end{tabular}

${ }^{\mathrm{a}}$ The ratios of both isomers were calculated with ${ }^{1} \mathrm{H}-\mathrm{NMR}$.

Table 2. Friedel-Crafts reaction of $\mathbf{3}$ and stoichiometric amounts of aromatics

We performed the F-C reaction in $\mathrm{TfOH}$ for compound $\mathrm{L}_{-}$ and $\mathrm{D}^{-} \mathbf{3}$ and some aromatic compounds (Table 2). Stereochemistry of the Asp derivative $\mathbf{3}$ was retained for F$\mathrm{C}$ products (Entries 1 and 2) in a good yield. Aromatics, which have electron donating substituents, easily reacted within an hour at $0^{\circ} \mathrm{C}$ in a high yield, because the inductive effect of the substituents played an important role. Toluene (Entries 3 and 4) was afforded $p$-substituted product (6) mainly and $o$-substituted product (7) of less than $5 \%$. Xylene derivatives (Entries 5 - 10) were also afforded 8-10 with a good yield. But anisole (Entries 11 and 12) was afforded the same degree of $p$ - (11) and $o$ - (12) isomers, which were easily purified with column chromatography. These results indicated that combinations of $\mathrm{TfOH}$ and activating groups in the aromatic compounds for nucleophilic substitution reduced activating energy differences between $O$ - and $p$ - formation more than combinations of $\mathrm{AlCl}_{3}$ and aromatics. ${ }^{7 \mathrm{c}}$ 1,2Dimethoxybenzene afforded only a less hindered (13) in a good yield (Entries 13 and 14). An F-C a reaction of aromatics bearing deactivating substituents such as nitro group (Entry 15) did not proceed even though the reaction was proceded at room temperature. F-C reaction of $N$-Ac or $N$-TFA-aniline also did not work (Entries 16 and 17). It was estimated that protonation of amide nitrogene with $\mathrm{TfOH}$ may decrease acidity in reaction mixture. F-C products (Lor $\mathrm{D}-\mathrm{5}, \mathbf{6 ,} \mathbf{8 - 1 3}$ ) were subsequently underwent hydrogenolysis of benzyl carbonyl with $\mathrm{H}_{2} / \mathrm{Pd}-\mathrm{C}$ in acetic acid followed by deprotection of TFA and methyl ester by $6 \mathrm{~N} \mathrm{HCl}$ aq. at $80^{\circ} \mathrm{C}^{16}$ to give hPhe derivatives a good yield (Scheme 1). Enantiomeric excess of these compounds was measured $[\alpha]_{\mathrm{D}}{ }^{7 f, 17}$ and chiral HPLC (CHIROBIOTIC T; eluted with $10 \% \mathrm{EtOH}-\mathrm{H}_{2} \mathrm{O}$; flow rate $1.0 \mathrm{ml} / \mathrm{min}$; UV detection at $210 \mathrm{~nm}$ ) for both enantiomers. Enantiomeric excess of all of the deprotected compounds was calculated $>99 \%$ in order to succeed asymmetric synthesis of hPhe derivatives. 


\section{Conclusion}

We established an efficient Friedel-Crafts reaction with stoichiometric amounts of aromatics and easily preparable Asp derivatives $\mathbf{3}$ as acyl donor, in good yields under mild conditions in $\mathrm{TfOH}$ at room temperature. Furthermore, the F-C reaction, which in previous reports ${ }^{7}$ had taken more than several hours with various Asp derivatives, was completed within an hour. Because amino acid derivatives, which are not easily dissolved in organic solvents, could be dissolved in $\mathrm{TfOH}$, the reaction mixture became a homogeneous system. After the reduction of the benzyl carbonyl group by using $\mathrm{H}_{2}-\mathrm{Pd} / \mathrm{C}$, deprotection TFA at $\alpha$ amino group and methyl ester at $\alpha$-carboxyl group, hPhe derivatives were afforded in a good overall yield (>90\%) and the asymmetric center of the product retained its configuration starting Asp derivatives. These synthetic routes will be applied to precious aromatics to derivatize side chain elongated aromatic amino acid derivatives via F$\mathrm{C}$ reactions in short steps.

\section{Acknowledgments}

This research was partially supported by a Ministry of Education, Science, Sports and Culture, Grant-in-Aid for Scientific Research on a Priority Area, 18032007, and for Scientific Research (C), 19510210. M.H. also thanks the Fugaku Foundation and Research for Promoting Technological Seeds for financial support for the study. R.M. thanks Obihiro University of Agriculture and Veterinary Medicine Committee for financial support for the study.<smiles>[R]c1cc([R4])c(C(=O)CC(NC(F)F)C(=O)OC)c([R])c1[R]</smiles>

$5,6,8-13$

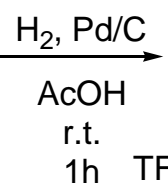

$$
\begin{array}{r}
\text { 5a L-96\%, D-94\% } \\
\text { 6a L-95\%, D-98\% } \\
\text { 8a L-98\%, D-97\% } \\
\text { 9a L-94\%, D-95\% } \\
\text { 10a L-98\%, D-96\% } \\
\text { 11a L-97\%, D-96\% } \\
\text { 12a L-99\%, D-98\% } \\
\text { 13a L-97\%, D-98\% }
\end{array}
$$

Scheme 1. Synthesis of hPhe derivatives<smiles>[R3]C(=C)C(CCC(N)C(=O)O)=C([R3])C</smiles>

5b L-99\%, D-98\% 6b L-96\%, D-99\%

8b L-97\%, D-98\%

9b L-98\%, D-99\%

10a L-98\%, D-96\%

11b L-98\%, D-95\%

12b L-99\%, D-99\%

13b L-98\%, D-99\%
$5 \mathrm{R}_{1}, \mathrm{R}_{2}, \mathrm{R}_{3}, \mathrm{R}_{4}=\mathrm{H}$

$6 \mathrm{R}_{1}=\mathrm{CH}_{3}, \mathrm{R}_{2}, \mathrm{R}_{3}, \mathrm{R}_{4}=\mathrm{H}$

$8 \mathrm{R}_{1}, \mathrm{R}_{2}=\mathrm{CH}_{3}, \mathrm{R}_{3}, \mathrm{R}_{4}=\mathrm{H}$

$9 \mathrm{R}_{1}, \mathrm{R}_{3}=\mathrm{CH}_{3}, \mathrm{R}_{2}, \mathrm{R}_{4}=\mathrm{H}$

$10 \mathrm{R}_{2}, \mathrm{R}_{4}=\mathrm{CH}_{3}, \mathrm{R}_{1}, \mathrm{R}_{3}=\mathrm{H}$

$11 \mathrm{R}_{1}=\mathrm{OCH}_{3}, \mathrm{R}_{2}, \mathrm{R}_{3}=\mathrm{H}$

$12 \mathrm{R}_{1}, \mathrm{R}_{2}=\mathrm{H}, \mathrm{R}_{3}=\mathrm{OCH}_{3}$

$13 \mathrm{R}_{1}, \mathrm{R}_{2}=\mathrm{OCH}_{3}, \mathrm{R}_{3}=\mathrm{H}$

\section{References}

1. (a) Mosberg, H. I.; Heyl, D. L.; Haaseth, R. C.; Omnaas, J. R.; Medzihradsky, F.; Smith, C. B. Mol. Pharm. 1990, 38, 924; (b) Abiko, T.; Sekino, H. Drug Dev Ind Pharm. 1998, 24, 569.

2. (a) Chang, C. Y.; Yang, T. K. Tetrahedron: Asymmetry 2003, 14, 2081; (b) Chang, C. Y.; Yang, T. K. Tetrahedron: Asymmetry 2003, 14, 2239.

3. Zhao, H.; Luo, R. G.; Wei, D.; Malhotra, S. V. Enantiomer, 2002, 7, 1 .

4. Barfoot, C. W.; Harvey, J. E.; Kenworthy, M. N.; Kilburn, J. P.; Ahmed, M.; Taylor, R. J. K. Tetrahedron, 2005, 61, 3403.

5. Yamada, M.; Nagashima, N.; Hasegawa, J.; Takahashi, S. Tetrahedron Lett. 1998, 39, 9019.

6. Xie, Y.; Lou, R.; Li, Z.; Mi, A.; Jiang, Y. Tetrahedron: Asymmetry. 2000, 11, 1487.

7. (a) Reifenrath, W. G.; Bertelli, D. J., Micklus M. J.; Fries, D. S. Tetrahedron Lett. 1976, 17, 1959; (b) Nordlander, J. E.; Payne, M. J.; Njoroge, F. G.; Vishwanath, V. M.; Han, G. R.; Laikos, G. D.; Balk, M. A. J. Org. Chem. 1985, 50, 3619; (c) Melillo, D. G.; Larsen, R. D.; Mathre, D. J.; Shukis, W. F.; Wood, A. W.; Colleluori, J. R. J. Org. Chem. 1987, 52, 5143;

(d) Griesbeck, A. G.; Heckroth, H. Synlett 1997, 11, 1243; (e) Lin, W.; He, Z.; Zhang, H.; Zhang, X.; Mi, A.; Jiang, Y. Synthesis 2001, 7, 1007; (f) Xu, Q.; Wang, G.; Wang, X.; Wu, T.; Pan, X.; Chan, A. S. C.; Yang, T. Tetrahedron: Asymmetry 2000, 11, 2309.

8. Weygand, F.; Klinke, P.; Eigen, I. Chem. Ber. 1957, 90, 1896.

9. It was reported that $\mathrm{F}-\mathrm{C}$ reaction of benzene and compound $\mathbf{1}$ was proceeded in 80 hours. $^{7 \mathrm{~b}}$

10. Katrizky, A. R.; Tao, H.; Jiang, R.; Suzuki, K.; Kirichenko, K. J. Org. Chem. 2007, 72, 407.

11. (a) Effenberger, F.; Epple, G. Angew. Chem. Int. Ed. Engl. 1972, 11, 299; (b) Germain, A.; Commeyras, A. J. Chem. Soc. Chem. Comm. 1972, 24, 1345; (c) Hwang, J. P.; Prakash, G. K. S.; Olah, G. A. Tetrahedron 2000, 56, 7199.

12. Khodaei, M. M.; Alizadeh, A.; Nazari, E. Tetrahedron Lett. 2007, 48, 4199.

13. Ariyoshi, Y.; Yamatani, T.; Uchiyama, N.; Sato, N. Bull. Chem. Soc. Jpn. 1972, 45, 2208.

14. Svete, J.; Stanocnik, B. J. Heterocycl. Chem. 1994, 31, 12591266.

15. General Method for Friedel-Crafts reaction with TfOH; Compound $3(0.1 \mathrm{mmol})$ and aromatic compound $(0.1 \mathrm{mmol})$ were dissolved in $\mathrm{TfOH}(0.5 \mathrm{ml}, 5.69 \mathrm{mmol})$ at $0^{\circ} \mathrm{C}$. The reaction mixture was allowed to warm to room temperature 
and stirred for 1hour, then poured into cold $-\mathrm{H}_{2} \mathrm{O} / \mathrm{AcOEt}$ $(40 / 40 \mathrm{ml})$ to quench the reaction. The organic layer was washed with $1 \mathrm{~N} \mathrm{HCl}$ aq., sat. $\mathrm{NaHCO}_{3}$ aq., $1 \mathrm{~N} \mathrm{HCl}$ aq. and sat. $\mathrm{NaCl}$ aq., and dried over $\mathrm{MgSO}_{4}$, then filtrated. The filtrate was concentrated to afford a F-C product.

16. Kirk, K. L. J. Org. Chem. 1980, 45, 2015.
17. (a) Petasis, N. A.; Zavialov, I. A. J. Am. Chem. Soc., 1997, 119, 445; (b) Long, A.; Baldwin, S. W. Tetrahedron Lett. 2001, 42, 5343; (c) Yamada, M.; Nagashima, N.; Hasegawa, J.; Takahashi, S. Tetrahedron Lett. 1998, 39, 9019; (d) Sabat, M.; Johnson, C. R. Org. Lett. 2000, 2, 1089. 


\section{Graphical Abstract}

To create your abstract, type over the instructions in the template box below.

Fonts or abstract dimensions should not be changed or altered.

Asymmetric and efficient synthesis of
homophenylalanine derivatives
via Friedel-Crafts reaction with trifluoromethanesulfonic acid
Ryo Murashige, Yuka Hayashi and Makoto Hashimoto *

